\title{
Regulation of tumour necrosis factor (TNF) induced apoptosis by soluble TNF receptors in Helicobacter pylori infection
}

\author{
J Shibata, H Goto, T Arisawa, Y Niwa, T Hayakawa, A Nakayama, N Mori
}

\begin{abstract}
Background-Tumour necrosis factor (TNF) is a predominant cytokine produced in the gastric mucosa of patients with Helicobacter pylori infection. TNF induces apoptosis in a variety of cells. The soluble TNF receptors (sTNF-Rs) can be divided into sTNF-RI and sTNF-RII, both of which inhibit TNF activity. However, their precise mechanisms remain unclear. Aim-To investigate the role of sTNF-Rs in $H$ pylori infection.

Methods-In 40 patients, production of TNF and sTNF-Rs in gastric mucosa was measured using biopsy specimens. In addition, in gastric epithelial cells, $s T N F-R$ release in response to TNF and the protective effect of sTNF-Rs against the cytotoxic and apoptotic activities of TNF were examined.
\end{abstract}

Results-TNF and sTNF-R expression was significantly higher in $H$ pylori positive than $H$ pylori negative patients. TNF dose-dependently induced sTNF-RI release from gastric epithelial cells. sTNFRII was also released from the cells. TNF decreased cell viability, but the effect was very small. A combination of antisTNF-RI and anti-sTNF-RII monoclonal antibodies significantly increased TNF induced cytotoxicity and apoptosis of gastric epithelial cells.

Conclusions-These results show that sTNF-Rs are actively produced in $H$ pylori infected gastric mucosa. sTNF-Rs appear to protect gastric epithelial cells from TNF induced apoptosis in $H$ pylori infection.

(Gut 1999;45:24-31)

Keywords: Helicobacter pylori; tumour necrosis factor; soluble TNF receptors; apoptosis; gastric mucosa; stomach

Helicobacter pylori infection is considered to be a risk factor for gastric cancer, ${ }^{1-4}$ but the mechanisms underlying its carcinogenic potential remain unclear. Recent studies have indicated an increase in gastric epithelial cell apoptosis in mucosal biopsy specimens from patients with $H$ pylori associated gastritis, ${ }^{5-8}$ and it is possible that excessive apoptosis caused by $H$ pylori infection may favour carcinogenesis. ${ }^{5-8}$ A variety of stimuli can induce apoptosis, such as tumour necrosis factor (TNF). ${ }^{9-11}$ Several studies have suggested that TNF is produced by $H$ pylor $i$ infection ${ }^{12-14}$ and is closely related to epithelial injury. ${ }^{11}$

TNF exerts pleiotropic effects by linking two high affinity TNF receptors (TNF-Rs) of 55 and $75 \mathrm{kDa}$ on a variety of cells. ${ }^{15}$ Soluble forms of the human $55 \mathrm{kDa}$ TNF-R (sTNF$\mathrm{RI}$ ) and the $75 \mathrm{kDa}$ receptor (sTNF-RII) appear to be released from the cell surface by proteolytic cleavage of the extracellular domains of these membrane associated receptors. ${ }^{16} 17$ Soluble receptors inhibit TNF activity by binding to TNF thus preventing its binding to membrane associated TNF-Rs. ${ }^{18} 19$ Recently, urine and serum from healthy, febrile, and HIV infected patients have been found to contain sTNF-Rs, ${ }^{20-22}$ but there have been no reports on sTNF-R expression in the stomach. The aims of this study were to investigate gastric TNF expression and sTNF-R release in patients with $H$ pylori infection, and to clarify the protective effect of sTNF-Rs against the cytotoxic and apoptotic activity of TNF.

\section{Methods}

PATIENTS

Forty asymptomatic individuals (36 men and four women aged 29-70 years; mean age, 51.9 years) who were having a routine health examination were studied. None of them had recently taken antibiotics, non-steroidal antiinflammatory drugs, or bismuth compounds. The project was approved by the Second Department of Internal Medicine at Nagoya University School of Medicine and the Aichi Prefectural Center for Health Care. Informed consent to the study was obtained from each subject, and upper gastrointestinal endoscopy was performed. Four biopsy specimens were obtained from the greater curvature at the gastric antrum and one was obtained from the gastric body. A biopsy specimen from the antrum and one from the body were used for the rapid urease test (CLO test). ${ }^{23}$ Another specimen from the gastric antrum was used for histological examination. The presence and severity of gastritis were graded in accordance with the Sydney system ${ }^{24}$; inflammation, activity, atrophy, and intestinal metaplasia were scored from 0 to 3 on haematoxylin and eosin stained sections ( 0 , none; 1 , mild; 2 , moderate; 3 , severe). The two residual specimens were used for tissue culture. Infection with $H$ pylori was defined by histological or CLO test positivity. 
TISSUE CULTURE

Biopsy specimens for culture were immediately placed in $1 \mathrm{ml}$ RPMI 1640 medium. After six hours, the medium was changed and further incubation was carried out in the presence of $5 \% \mathrm{CO}_{2}$ at $37^{\circ} \mathrm{C}$ for 24 hours. At the end of the incubation, culture supernatants were collected and stored at $-80^{\circ} \mathrm{C}$ until assayed. The specimens were homogenised in $0.5 \mathrm{ml} 1 \mathrm{M}$ $\mathrm{NaOH}$ at $100^{\circ} \mathrm{C}$ for 10 minutes and neutralised with the same volume of $1 \mathrm{M} \mathrm{HCl}$. Aliquots of the homogenate were assayed for total protein by the Bio-Rad Protein Assay (Bio-Rad Laboratories, Hercules, California, USA).

MEASUREMENT OF TNF, STNF-RI, AND STNF-RII IN TISSUE CULTURE

Concentrations of TNF, sTNF-RI, and sTNFRII in tissue culture supernatants were determined by enzyme linked immunosorbent assay (ELISA) (Quantikine; R\&D Systems, Minneapolis, Minnesota, USA). TNF and sTNF-R concentrations were expressed as $\mathrm{pg} / \mathrm{mg}$ protein.

CELL LINE

A human gastric epithelial cell line MKN45 was provided by the Japanese Cancer Research Resources Bank. Cells were maintained in RPMI 1640 supplemented with $10 \%$ fetal bovine serum, penicillin $\left(10^{5} \mathrm{U} / \mathrm{l}\right)$, and streptomycin $(100 \mathrm{mg} / \mathrm{l})$. In some comparative studies, a human gastric epithelial cell line, KATO III, was also used. Cells were maintained in Dulbecco's modified Eagle's medium supplemented as for the MKN45 cells.

MEASUREMENT OF TNF, STNF-RI, AND STNF-RII IN CELL CULTURE

Concentrations of sTNF-RI and sTNF-RII in cell culture supernatants were determined by the same method as the tissue culture. Briefly, MKN45 cells $\left(2 \times 10^{5} /\right.$ well $)$ were plated into 12 -well culture plates and cultured in $1 \mathrm{ml}$ complete medium with or without various concentrations of TNF (1-100 ng/ml) for 24 hours at $37^{\circ} \mathrm{C}$. KATO III cells were also plated by the same method and cultured with or without TNF (100 ng/ml).

3-(4,5 - DIMETHYLTHIAZOL - 2-YL) - 2,5 - DIPHENYLTETRAZOLIUM BROMIDE (MTT) ASSAY

The effect of human TNF (Bachem Fine Chemicals Inc, Torrance, California, USA) on MKN45 cell viability was evaluated by the MTT reduction assay (Chemicon International Inc, Temecula, California, USA). Briefly, MKN45 cells $\left(2 \times 10^{3} /\right.$ well $)$ were plated into 96-well culture plates and cultured in 100 $\mu l$ complete medium with or without various concentrations of TNF $(1-100 \mathrm{ng} / \mathrm{ml})$. After 24-96 hours, MTT $(0.5 \mathrm{mg} / \mathrm{ml})$ was added and the reaction was allowed to proceed for four hours at $37^{\circ} \mathrm{C}$, after which intracellular formazan was extracted with $100 \mu \mathrm{l} /$ well acid propan-2-ol. The absorbance of each well was measured with a dual wavelength automated plate reader (MTP-100; Corona Electric Co, Ibaragi, Japan) at 570/650 nm. ${ }^{25}$
This method was also used to investigate effects of anti-sTNF-R monoclonal antibodies (R\&D Systems) on cell viability. MKN45 cells $\left(2 \times 10^{3} /\right.$ well $)$ were cultured in the presence of anti-sTNF-RI and/or anti-sTNF-RII monoclonal antibodies for three hours, and further incubated with TNF $(100 \mathrm{ng} / \mathrm{ml})$ for 21 hours. The conditions were TNF + anti-sTNF-RI monoclonal antibody $(40 \mu \mathrm{g} / \mathrm{ml})$, TNF + antisTNF-RII monoclonal antibody $(40 \mu \mathrm{g} / \mathrm{ml})$, TNF + anti-sTNF-RI monoclonal antibody $(10 \mu \mathrm{g} / \mathrm{ml})+$ anti-sTNF-RII monoclonal antibody $(10 \mu \mathrm{g} / \mathrm{ml})$ and TNF + anti-sTNF-RI monoclonal antibody $(20 \mu \mathrm{g} / \mathrm{ml})+$ anti-sTNFRII monoclonal antibody $(20 \mu \mathrm{g} / \mathrm{ml})$. The medium was changed daily until the cells had been incubated for 96 hours.

TARGET OF ANTI-STNF-R MONOCLONAL ANTIBODIES

To investigate whether anti-sTNF-Rs monoclonal antibodies used in this study bind to shed TNF-Rs rather than the membrane bound ones, the following studies were carried out. We extracted proteins from cell lysate of untreated MKN45 cells and cell culture supernatant treated with $100 \mathrm{ng} / \mathrm{ml} \mathrm{TNF}$ and performed western blot analysis. The cell culture supernatant was concentrated using a Microcon microconcentrator with $50 \mathrm{kDa}$ cut off membrane. Samples (5 $\mu \mathrm{g} / \mathrm{lane}$ ) were electrophoresed and transferred to the membrane. After being blocked, the membrane was incubated with a mouse monoclonal antibody against human sTNF-RI and sTNF-RII. The membrane was washed and then incubated with peroxidase conjugated goat anti-mouse IgG.

DNA ELECTROPHORESIS

Genomic DNA was extracted from untreated and treated (TNF $(100 \mathrm{ng} / \mathrm{ml})$ and TNF (100 $\mathrm{ng} / \mathrm{ml})+$ anti-sTNF-RI monoclonal antibody $(20 \mu \mathrm{g} / \mathrm{ml})+$ anti-sTNF-RII monoclonal antibody $(20 \mu \mathrm{g} / \mathrm{ml}))$ cells $\left(1 \times 10^{5} /\right.$ well $)$ after 96 hours. Briefly, cells were harvested and lysed in $10 \mathrm{mM}$ Tris/ $\mathrm{HCl}(\mathrm{pH} 8.0)$ containing $10 \mathrm{mM}$ EDTA, $150 \mathrm{mM} \mathrm{NaCl}, 0.1 \%$ sodium dodecyl sulphate and $100 \mu \mathrm{g} / \mathrm{ml}$ proteinase $\mathrm{K}$ for one hour at $55^{\circ} \mathrm{C}$, and then gently mixed for 16 hours at $37^{\circ} \mathrm{C}$. DNA was then extracted twice with phenol and phenol/chloroform, and recovered in the aqueous phase. DNA was precipitated in ethanol, spun for $15 \mathrm{~min}$ at $15000 \mathrm{~g}$, and resuspended in TE buffer (10 $\mathrm{mM}$ Tris/HCl, pH 8.0, 1 mM EDTA) containing $100 \mu \mathrm{g} / \mathrm{ml} \mathrm{RNase}$ for at least one hour at $37^{\circ} \mathrm{C}$. Electrophoretic separation of DNA (20 $\mu \mathrm{g}$ per lane) was carried out on $2 \%$ agarose gel.

FLOW CYTOMETRIC ANALYSIS

To detect apoptosis, flow cytometric analysis was performed as previously described. ${ }^{26-28}$ Untreated and treated (TNF $(100 \mathrm{ng} / \mathrm{ml})$ and TNF (100 ng/ml) + anti-sTNF-RI monoclonal antibody $(20 \mu \mathrm{g} / \mathrm{ml})+$ anti-STNF-RII monoclonal antibody $(20 \mu \mathrm{g} / \mathrm{ml}))$ MKN45 cells and KATO III cells $\left(1 \times 10^{4} /\right.$ well $)$ were lysed and stained by adding hypotonic propidium iodide $(50 \mu \mathrm{g} / \mathrm{ml}$ in $0.1 \%$ sodium citrate and $0.5 \%$ 

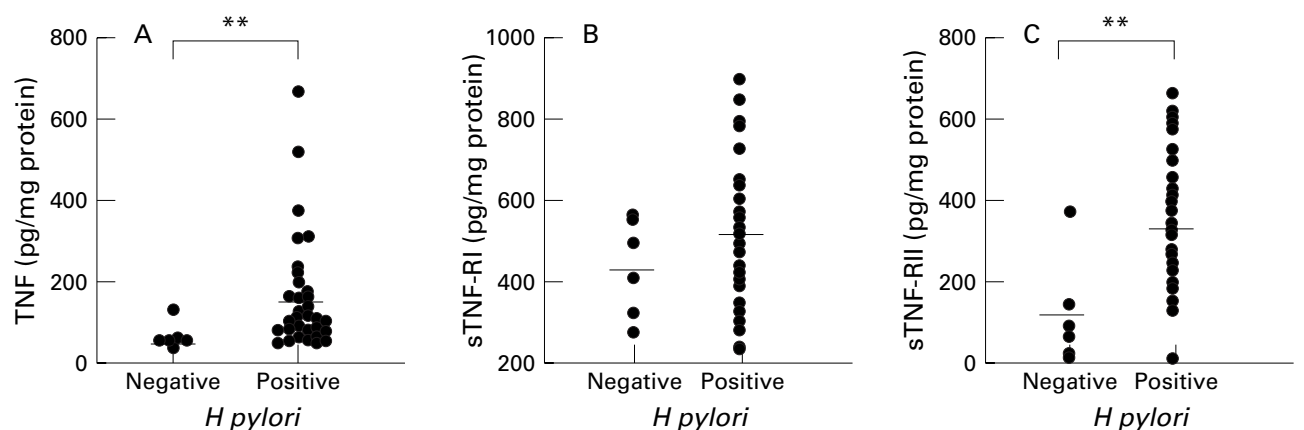

Figure 1 Concentrations of tumour necrosis factor (TNF) and soluble TNF receptors (sTNF-Rs) in tissue culture supernatants of antral mucosa from patients with and without $H$ pylori infection. (A) TNF; (B) sTNF-RI; (C) $s T N F-R I I$. Bars represent mean values. TNF and sTNF-RII levels increased significantly in H pylori positive subjects $\left({ }^{* *} p<0.01\right)$

Nonidet P40). After being stained, cells were analysed on a FACScan flow cytometer (EPICS XL; Coulter, Miami, Florida, USA). For both MKN45 and KATO III cells, 10000 cells were collected. Data were analysed as two dimensional frequency contour plots of forward scatter (linear scale) against propidium iodide stained DNA content (logarithmic scale).

POLYMERASE CHAIN REACTION (PCR) PRIMERS FOR TNF-RS

Oligonucleotide primers were synthesised using a DNA synthesiser (Gibco BRL Life Technologies, Rockville, Maryland, USA) and were designed from the published sequences. ${ }^{29} 30$ The forward (sense) and reverse (antisense) primers for TNF-RI were 5'-GTGCTGTTGCCCCTGGTCAT-3' and 5'-TTCTGCAGCTCCAGCCG-3' respectively, with the PCR product being $543 \mathrm{bp}$. The forward and reverse primers for TNF-RII were 5'-CTCACTTGCCTGC-
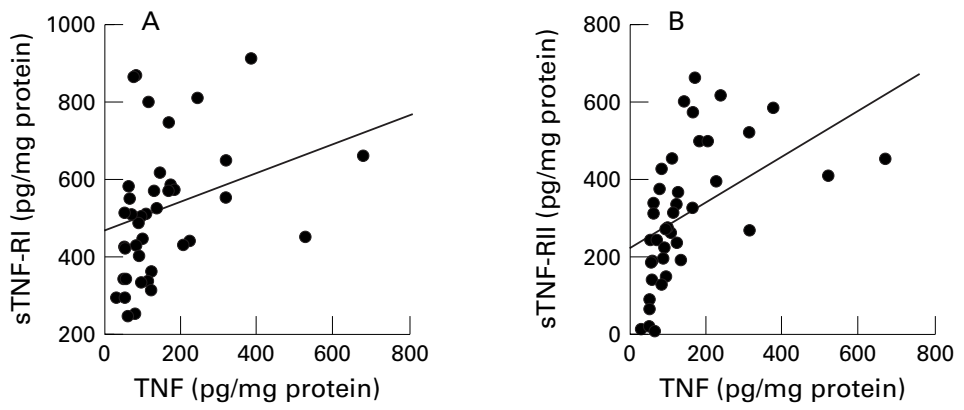

Figure 2 Relation between tumour necrosis factor (TNF) and soluble TNF receptor (sTNF-R) concentrations in tissue culture supernatants from $H$ pylori positive subjects. (A) $s T N F-R I, p<0.05, r=0.344$; (B) $s T N F-R I I, p<0.01, r=0.523$.
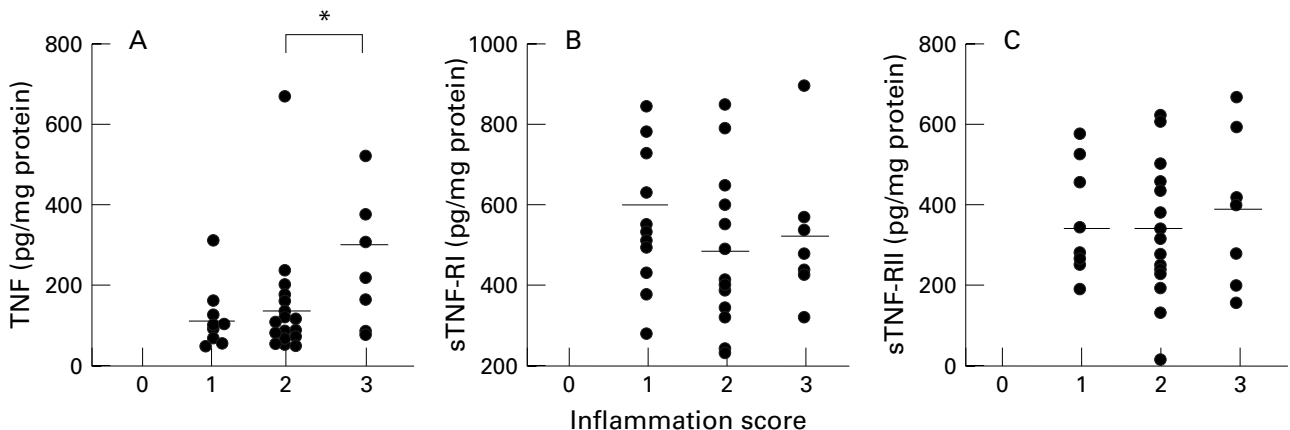

Figure 3 Comparison of tumour necrosis factor (TNF) and soluble TNF receptor (sTNF-R) expression according to inflammation score. (A) TNF, ${ }^{\star} p<0.05$; (B) sTNF-RI; (C) sTNF-RII. Bars represent mean values.
CGATAAGG-3' and 5'-TCCCAGCATCAGGCACTCCAA-3' respectively, with the PCR product being $450 \mathrm{bp}$. Forward (sense) and reverse (antisense) primers for $\beta$-actin were 5'-CGGAACCGCTCATTGCC-3' and 5'ACCCACACTGTGCCCATCTA-3', yielding a 292 bp product.

DETECTION OF TNF-RI AND TNF-RII MRNA BY REVERSE TRANSCRIPTASE PCR

To determine whether TNF-RI and TNF-RII mRNA were expressed in MKN45 and KATO III cells with and without TNF (100 ng/ml) treatment for 96 hours, we extracted total cellular RNA from freshly isolated cells and performed reverse transcriptase PCR analysis with TNF-RI or TNF-RII specific primers. RNA extraction was performed as follows. ${ }^{29-33}$ Cells were lysed in Trisol (Gibco BRL Life Technologies), and, after chloroform extraction, RNA was precipitated with propan-2-ol/ ethanol and dissolved in diethyl pyrocarbonate-treated water. Then $7 \mu \mathrm{l}$ of RNA solution was mixed with $1 \mu l \quad 0.5 \mathrm{mg} / \mathrm{ml}$ oligo(dT) and $4 \mu \mathrm{l}$ of $5 \times$ buffer $(250 \mathrm{mM}$ Tris/ $\mathrm{HCl}, \mathrm{pH} 8.3,375 \mathrm{mM} \mathrm{KCl}$ ) for two minutes at $95^{\circ} \mathrm{C}$. After the RNA solution had been left to stand at $37^{\circ} \mathrm{C}$ for 30 minutes, it was mixed with $2 \mu \mathrm{l} 0.1 \mathrm{M}$ dithiothreitol, $4 \mu \mathrm{l} 2.5 \mathrm{mM}$ dNTPs (Takara Shuzo Co, Kyoto, Japan), $1 \mu 110 \mathrm{U} / \mu \mathrm{l}$ RNase inhibitor (Gibco BRL Life Technologies) and $1 \mu \mathrm{l}$ of $200 \mathrm{U} / \mu \mathrm{l}$ Moloney murine leukaemia virus reverse transcriptase. After reaction at $37^{\circ} \mathrm{C}$ for 60 minutes, the tube was kept at $90^{\circ} \mathrm{C}$ for five minutes, followed by chilling on ice. The cDNA was then amplified in a mixture consisting of $2 \mu \mathrm{l} 0.63 \mathrm{U} / \mu \mathrm{l} \mathrm{recom}-$ 


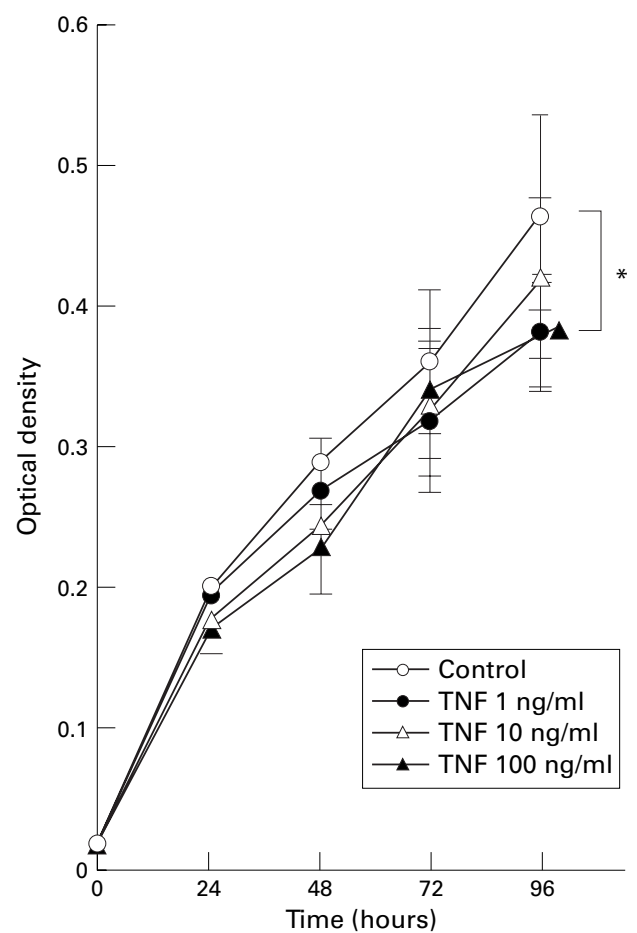

Figure 4 Effect of tumour necrosis factor (TNF) on MKN45 cell viability. Data are expressed as mean (SD) $(n=8) .{ }^{*} p<0.05$. There are significant differences $(p<0.05)$ between control and $1 \mathrm{ng} / \mathrm{ml}$ and $100 \mathrm{ng} / \mathrm{ml}$ TNF
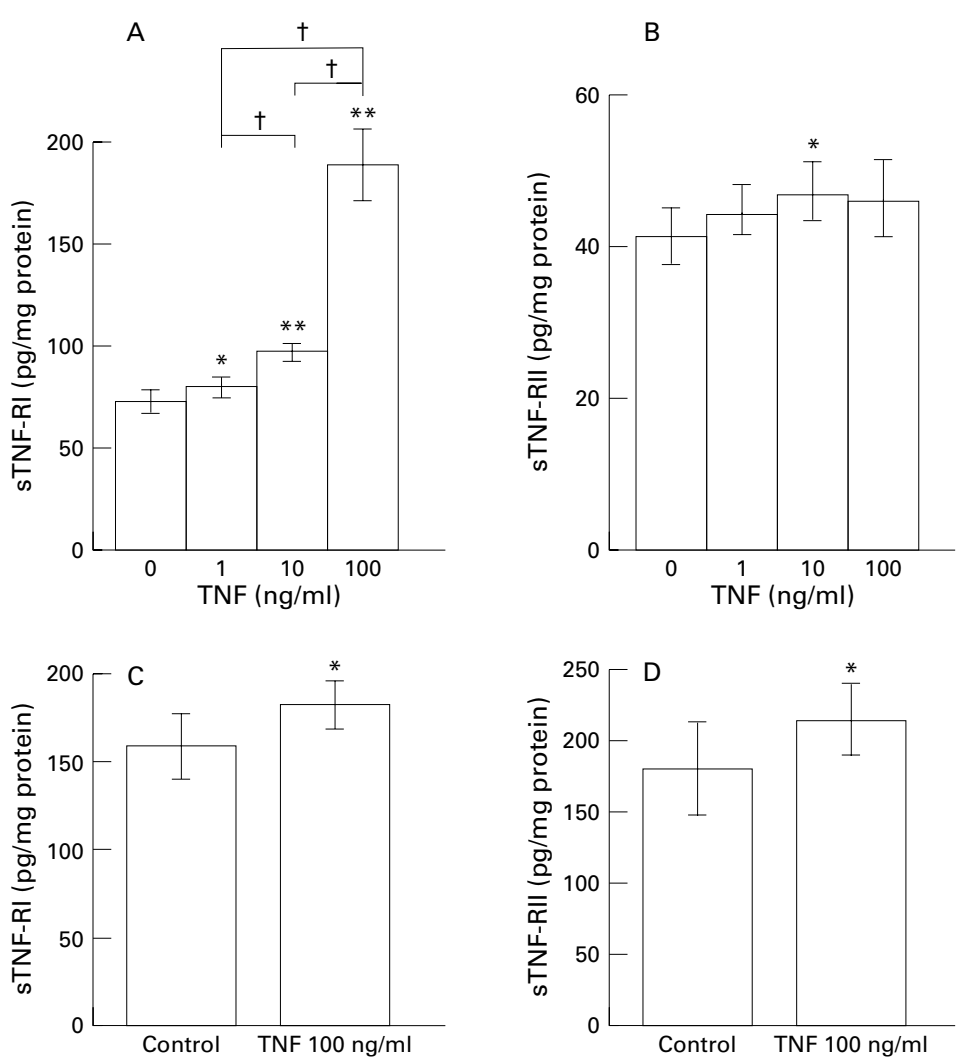

Figure 5 Release of soluble tumour necrosis factor (TNF) receptors (sTNF-Rs) from gastric epithelial cells by various concentrations of TNF for 24 hours. ( $A$ ) sTNF-RI from MKN45 cells; (B) sTNF-RII from MKN45 cells; (C) sTNF-RI from KATO III cells; (D) sTNF-RII from KATO III cells. Data are expressed as mean $(S D)(n=8)$. ${ }^{\star} p<0.05$, ${ }^{\star} p<0.01$ v control. $t p<0.01$. binant Taq DNA polymerase (Takara Shuzo Co), $2 \mu 12.5 \mathrm{mM}$ dNTPs, $20 \mu \mathrm{M}$ forward and reverse primers diluted to the appropriate concentration in distilled water $(0.2 \mu \mathrm{M}$ for both TNF-RI and TNF-RII), $2.5 \mu \mathrm{l} 10 \times \mathrm{PCR}$ buffer (100 mM Tris/HCl, pH 8.3, $500 \mathrm{mM}$ $\mathrm{KCl}, 15 \mathrm{mM} \mathrm{MgCl}_{2}$ ), and distilled water. The PCR was performed in an automated thermocycler (Takara Shuzo Co) at $94^{\circ} \mathrm{C}$ for four minutes and then 30 cycles of the sequence TNF-RI (one minute at $94^{\circ} \mathrm{C}, 1.5$ minutes at $65^{\circ} \mathrm{C}$, and three minutes at $72^{\circ} \mathrm{C}$ ) or TNF-RII (one minute at $94^{\circ} \mathrm{C}$, two minutes at $60^{\circ} \mathrm{C}$, and three minutes at $72^{\circ} \mathrm{C}$ ). Then $10 \mu \mathrm{l}$ of the PCR product was electrophoresed on $2 \%$ agarose gel and visualised by ethidium bromide staining. $\beta$-Actin was used as the internal standard.

\section{IMMUNOBLOTTING}

To investigate whether or not membrane associated TNF-RI and TNF-RII were expressed by MKN45 and KATO III cells or were changed by TNF $(100 \mathrm{ng} / \mathrm{ml})$ treatment for 96 hours, we extracted proteins from the cells and performed western blot analysis. Samples (5 $\mu \mathrm{g}$ /lane) were electrophoresed on $10 \%$ sodium dodecyl sulphate polyacrylamide gel under reducing conditions. After electrophoresis, the proteins were transferred electrophoretically to an Immobilon membrane (Millipore, Bedford, Massachusetts, USA). After being blocked, the membrane was incubated for one hour with a mouse polyclonal antibody against human TNF-RI (Genzyme Corp, Boston, Massachusetts, USA) and a goat polyclonal antibody against human TNF-RII (Santa Cruz Biotechnology, Santa Cruz, California, USA). The membrane was washed three times for 15 minutes each with TBS-T (150 mM $\mathrm{NaCl}, 0.1 \% \mathrm{NaN}_{3}, 50 \mathrm{mM}$ Tris/HCl, $\mathrm{pH}$ 7.6, $0.2 \%$ Tween 20 ), and then incubated for one hour with peroxidase conjugated goat antimouse IgG (Amersham Pharmacia Biotech UK Ltd, Amersham, Bucks, UK) and rabbit anti-goat IgG (Santa Cruz Biotechnology). After a wash with TBS-T, the membrane was incubated with enhanced chemiluminescence/ western blot detecting reagent (Amersham Corp, Arlington Heights, Illinois, USA).

\section{STATISTICAL ANALYSIS}

Differences in TNF and sTNF-R production between $H$ pylori infected and non-infected subjects were calculated using the MannWhitney U test. Correlations between TNF and sTNF-Rs were calculated using Spearman's rank correlation coefficients. The relation between histology and TNF or sTNF-Rs was analysed using the Kruskal-Wallis test plus one factor analysis of variance or Scheffe's F test. Statistical analysis of the effect of TNF on MKN45 cell viability was performed using two factor analysis of variance plus Student's $t$ test. Apoptosis by flow cytometric analysis was analysed using $\chi^{2}$ test. Other data on MKN45 cells and KATO III cells were analysed using Student's $t$ test. The results were expressed as mean (SD). $\mathrm{p}<0.05$ was considered significant. 
A

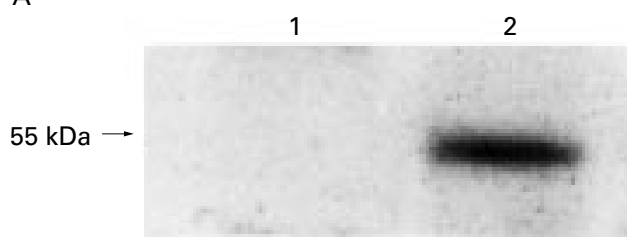

B

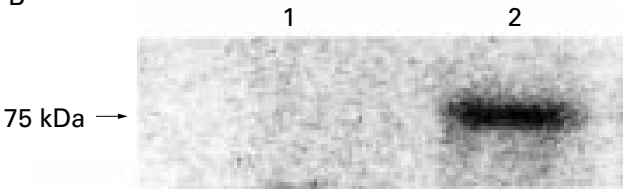

Figure 6 Target of anti-soluble tumour necrosis factor receptor (sTNF-R) monoclonal antibodies. (A) Anti-sTNF-RI; (B) anti-sTNF-RII. Lane 1, MKN45 cell lysate; lane 2, MKN45 cell culture supernatant.

\section{Results}

TNF AND STNF-R LEVELS IN TISSUE CULTURE Production of TNF and sTNF-RII was significantly greater in $H$ pylori positive subjects $(\mathrm{n}=$ 34) than in $H$ pylori negative subjects $(\mathrm{n}=6)$ $(\mathrm{p}<0.01$ for both TNF and sTNF-RII) (fig 1A,C). Production of sTNF-RI was also higher in $H$ pylori positive subjects than in $H$ pylori negative subjects, but the difference was not significant (fig 1B).

There was a significant correlation between the TNF and sTNF-RI levels (fig 2A) as well as TNF and sTNF-RII levels (fig 2B) in the medium of tissue cultures from $H$ pylori positive patients $(\mathrm{p}<0.05$ and $\mathrm{p}<0.01$ respectively).

Moreover, the TNF level correlated significantly with the inflammation score $(p<0.05)$ (fig 3A). However, no significant correlation was found between sTNF-R levels and the inflammation score (fig 3B,C). The activity, atrophy, and metaplasia scores did not corre-

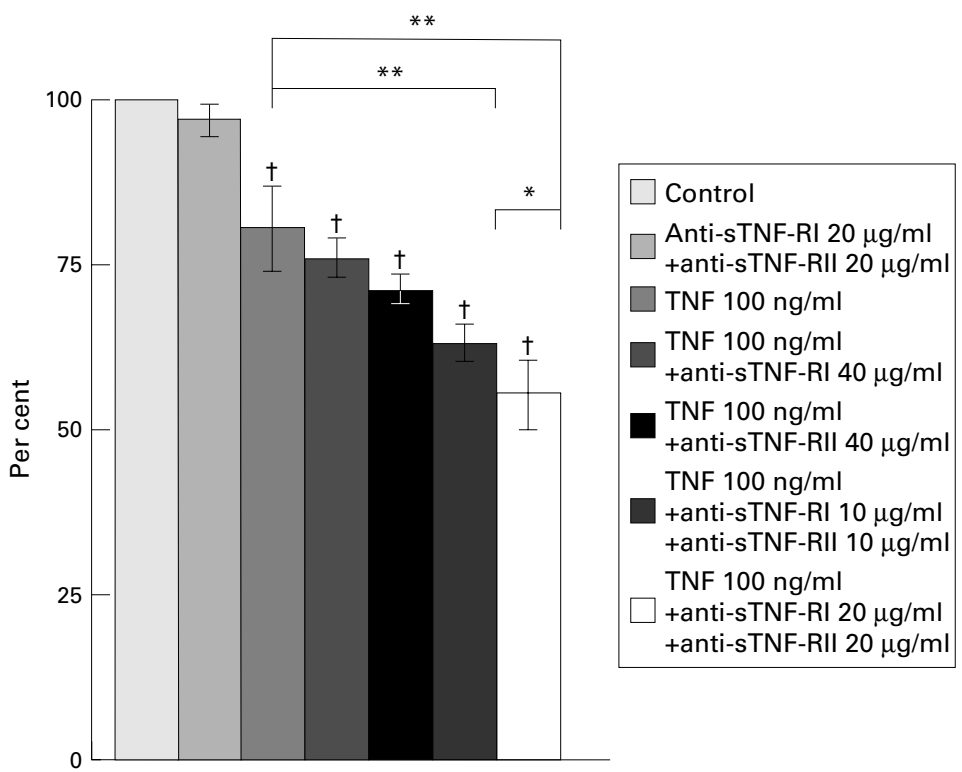

Figure 7 Influence of anti-soluble tumour necrosis factor (TNF) receptor I (sTNF-RI) monoclonal antibody and/or anti-sTNF-RII monoclonal antibody on TNF cytotoxicity. The reduction in cell viability was dependent on the concentrations of both types of anti-sTNF-R monoclonal antibody. Data are expressed as mean $(S D)(n=6) . t p<0.01 v$ control. ${ }^{\star} p<0.05 ;{ }^{\star *} p<0.01$. late with either TNF or sTNF-R levels (data not shown).

EFFECT OF TNF ON MKN45 CELL VIABILITY

After incubation of MKN45 cells with TNF for 96 hours, cell viability was slightly decreased and this was not dependent on the dose (fig 4).

EFFECT OF TNF ON STNF-R RELEASE FROM GASTRIC EPITHELIAL CELLS

In contrast, TNF caused dose dependent sTNF-RI release after culture with MKN45 cells for 24 hours (fig 5A) (the maximal response was 188.159 (17.772) $\mathrm{pg} / \mathrm{ml}$ protein) $(\mathrm{p}<0.01)$. sTNF-RII was also released from MKN45 cells and maximal stimulation was observed with $10 \mathrm{ng} / \mathrm{ml} \mathrm{TNF}$ (46.765 (3.932) $\mathrm{pg} / \mathrm{ml}$ protein) $(\mathrm{p}<0.05)$ (fig $5 \mathrm{~B}) . \mathrm{sTNF}-\mathrm{RI}$ (fig 5C) and sTNF-RII (fig 5D) were also released from KATO III cells after culture with 100 $\mathrm{ng} / \mathrm{ml} \mathrm{TNF}$.

TARGET OF ANTI-STNF-R MONOCLONAL ANTIBODIES

Anti-sTNF-R monoclonal antibodies bind to shed TNF-Rs, but not to membrane bound TNF-Rs (fig 6A,B).

EFFECT OF ANTI-STNF-R MONOCLONAL ANTIBODIES ON MKN45 CELL VIABILITY

As shown in fig 7 , cells cultured with either TNF + anti-sTNF-RI monoclonal antibody $(40 \mu \mathrm{g} / \mathrm{ml})$ or TNF + anti-sTNF-RII monoclonal antibody $(40 \mu \mathrm{g} / \mathrm{ml})$ showed a slight decrease in MTT reduction to about $95 \%$ and $88 \%$ respectively of that for cells cultured with TNF alone. Furthermore, combined treatment with TNF and both monoclonal antibodies (10 or $20 \mu \mathrm{g} / \mathrm{ml}$ ) significantly reduced cell viability to $78 \%$ and $69 \%$ of that for TNF alone at 10 and $20 \mu \mathrm{g} / \mathrm{ml}$ respectively $(\mathrm{p}<0.01 v$ TNF alone). Reduction of cell viability was dependent on the concentrations of both anti-sTNF-R monoclonal antibodies $(\mathrm{p}<0.05)$. However, treatment with monoclonal antibodies alone or with control goat IgG $(40 \mu \mathrm{g} / \mathrm{ml})$ did not alter cell viability (data not shown).

DNA ELECTROPHORESIS

This reduction in cell viability induced by treatment with TNF and anti-sTNF-RI monoclonal antibody and anti-sTNF-RII monoclonal antibody was ascribed to apoptotic DNA fragmentation (DNA ladder), although TNF alone showed a weak DNA ladder (fig 8).

DETECTION OF APOPTOSIS BY FLOW CYTOMETRIC ANALYSIS

Three cell subpopulations were identified. We have designated these subpopulations area 1 (high DNA content), 2 (low DNA content and markedly decreased forward scatter), and 3 (low DNA content and increased forward scatter). We consider that area 1 contains normal diploid cells. Apoptotic cells were recognised in the low DNA content area (hypodiploid cell population), ${ }^{28}$ and cell debris was recognised appropriately raising the forward scatter threshold, ${ }^{26}$ so we consider that area 2 contains debris and area 3 contains apoptotic cells. In 
1 2

3

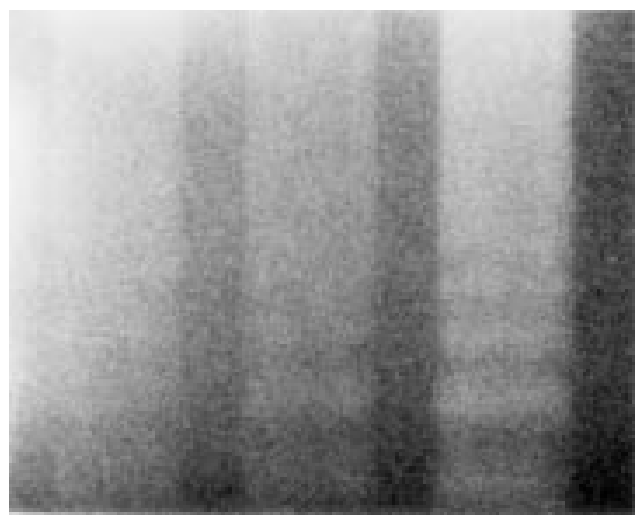

Figure 8 Agarose gel electrophoresis of DNA extracted from MKN45 cells exposed to tumour necrosis factor (TNF) and anti-soluble TNF receptor (sTNF-R) monoclonal antibodies for 96 hours. Lane 1, control (no $T N F$ or anti-sTNF-R monoclonal antibodies); lane 2 , TNF $100 \mathrm{ng} / \mathrm{ml}$; lane 3, TNF $100 \mathrm{ng} / \mathrm{ml}+$ anti-sTNF-RI and anti-sTNF-RII monoclonal antibodies $20 \mu \mathrm{g} / \mathrm{ml}$. Addition of anti-sTNF-R monoclonal antibodies induced a more conspicuous DNA ladder.

MKN45 and KATO III control groups, the percentage of apoptosis was 3.0. We found a much higher percentage of MKN45 cells showing apoptosis with anti-sTNF-R monoclonal antibody treatment (9.6) than the percentage of the same cells treated with TNF alone (6.2) $(\mathrm{p}<0.01)$ (fig 9A). Moreover, these effects were stronger on KATO III cells than on MKN45 cells and the percentage of apoptosis with anti-sTNF-R monoclonal antibody treatment was greater than that with only TNF treatment (20.2 and 5.9 respectively) $(\mathrm{p}<0.01)$ (fig 9B).

A
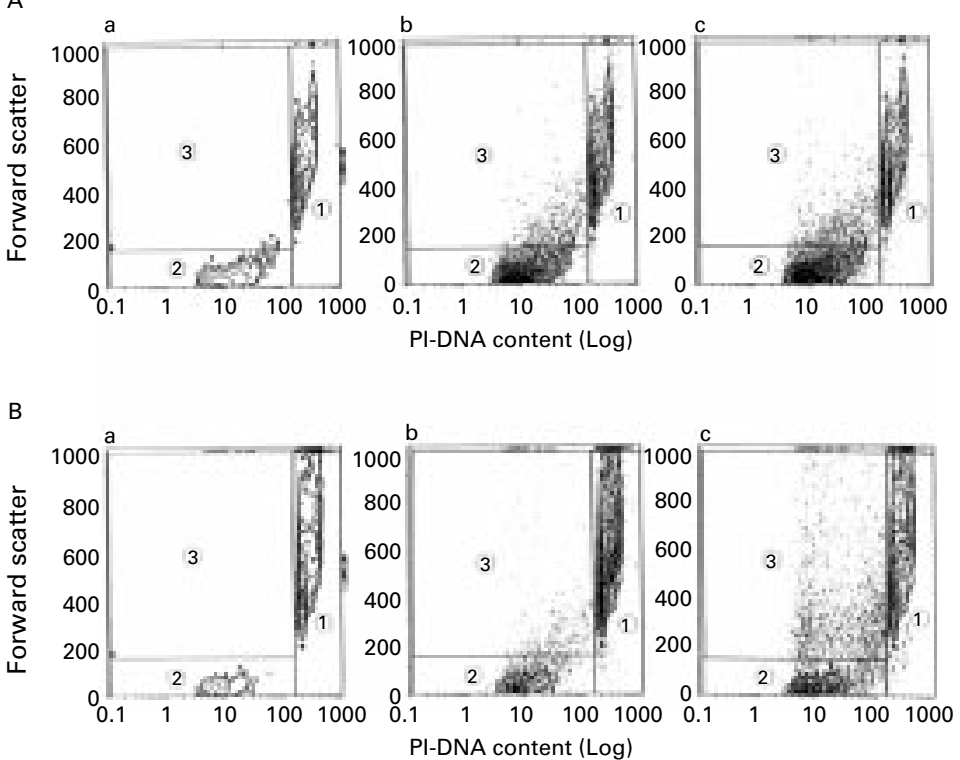

Figure 9 Detection of apoptosis by flow cytometric analysis. (A) MKN45 cells. (a) Cells were cultured for 96 hours in control medium; (b) cells were treated with tumour necrosis factor (TNF) $100 \mathrm{ng} / \mathrm{ml}$ alone; (c) cells were treated with TNF $100 \mathrm{ng} / \mathrm{ml}+$ anti-soluble $T N F$ receptor $I$ (sTNF-RI) and anti-s TNF-RII monoclonal antibodies $20 \mu \mathrm{g} / \mathrm{ml}$. (B) KATO III cells. (a) -(c) are the same as for MKN45 cells. These are representative of two dimensional frequency contour plots of forward scatter (linear scale) v propidium iodide (PI)-DNA content (logarithmic scale). Apoptosis was recognised in area $3 .(A)(a),(b)$, (c): $3.0 \%, 6.2 \%, 9.6 \%$ respectively. (B) (a), (b), (c): 3.0\%, 5.9\%, 20.2\% respectively. Addition of anti-sTNF-R monoclonal antibodies induced apoptosis more conspicuously $(p<0.01)$.
EXPRESSION OF MRNA FOR TNF-RI AND TNF-RII Figure 10A shows that the TNF-RI specific primers amplified a $543 \mathrm{bp}$ fragment from TNF treated and untreated MKN45 cells. This was consistent with the fragment size predicted from the TNF-RI sequence. Similar results were obtained for TNF-RII (fig 10B), with the predicted $450 \mathrm{bp}$ fragment being found in TNF treated and untreated MKN45 cells. These results suggest that mRNA for both TNF-RI and TNF-RII were expressed equally by MKN45 cells with or without TNF treatment. In further experiments, we obtained similar results for TNF-RI (fig 10C) and TNF-RII (fig 10D) in TNF treated and untreated KATO III cells. These results show that mRNA for both TNF-RI and TNF-RII treated with TNF were expressed slightly more strongly than that without treatment.

EXPRESSION OF MEMBRANE ASSOCIATED TNF-RI AND TNF-RII

In contrast, fig $11 \mathrm{~A}$ shows a decrease in $55 \mathrm{kDa}$ TNF-RI and fig $11 \mathrm{~B}$ shows a decrease in 75 kDa TNF-RII expression also in MKN45 cells after addition of TNF for 96 hours. Similar results were observed in experiments using KATO III cells (fig 11C,D).

\section{Discussion}

Recently, soluble receptors have been the subject of much attention. For example, there are reports that animals with septicaemia can be protected from shock by administration of recombinant soluble receptor. ${ }^{19}$ In the clinical realm, application of recombinant gene products including TNF receptors and interleukin 4 receptors is being investigated. However, there is still insufficient understanding of the relation between TNF and sTNF-Rs in gastric mucosa.

This investigation shows that the TNF level correlates significantly with the inflammation score but not with the activity score, suggesting that TNF may be released from inflammatory cells, mainly mononuclear cells. On the other hand, the sTNF-R levels did not correlate with the inflammation and activity scores but correlated significantly with TNF level. This suggests that sTNF-Rs may be released by cells within the gastric mucosa, such as epithelial cells, rather than by inflammatory cells. We selected asymptomatic subjects in order to obtain unbiased results. Because of the predominance of men in the Japanese workforce, $90 \%$ of the subjects in this study were male.

It has been reported that normal gastric chief cells express the TNF-Rs and that TNF induces cytotoxicity in these cells. ${ }^{34}$ Thus we focused on gastric epithelial cells, and investigated the effect of TNF on the epithelium, and the role of sTNF-Rs in counteracting that effect by experiments using MKN45 cells. In some experiments, KATO III cells were also used for comparative studies. In this study, we used a gastric epithelial cancer cell line, because we could not obtain cultured normal gastric epithelial cells established for experimentation. We think that release of sTNF-Rs and cytotoxicity induced by TNF are not only 
characteristics of cancer cells but also of normal gastric epithelial cells. ${ }^{34}$ In the presence of TNF, sTNF-R release from MKN45 and KATO III cells increased, and cell damage induced by TNF was increased by STNF-R neutralising antibodies, suggesting that the effect of TNF may be regulated through sTNF-R release from gastric epithelial cells. Furthermore, the TNF-R response to TNF was not related to a change at the mRNA level in MKN45 cells, but rather to a decrease at the protein level. From these results, we were able to confirm that TNF-R expression was downregulated. If we assume that TNF-R expression was downregulated, it is reasonable to assume that a decrease in MKN45 cell viability was not dependent on TNF concentration (fig 4). Receptor downregulation may be one mechanism of protecting against the harmful effects of TNF. Downregulation of the TNF-Rs has

been reported previously. ${ }^{35} 36$ We showed that TNF induced apoptosis was regulated by both increased sTNF-R release from gastric epithelial cells and decreased membrane surface TNF-R expression on these cells. Indeed, the host defence mechanism is thought to involve shedding of the extracellular domain of the receptor, which not only reduces the number of binding sites at the cell surface, but also increases binding protein for circulating TNF and thus prevents attachment to cell surface receptors.

Differences in the actions of TNF-RI and TNF-RII on the membrane surface have already been reported. ${ }^{15}$ However, there have been no reports on differences in the actions of sTNF-RI and sTNF-RII. Our investigations were also unable to clarify differences in the functions of the two sTNF-Rs. In this study, neutralisation of either sTNF-RI or sTNF-RII
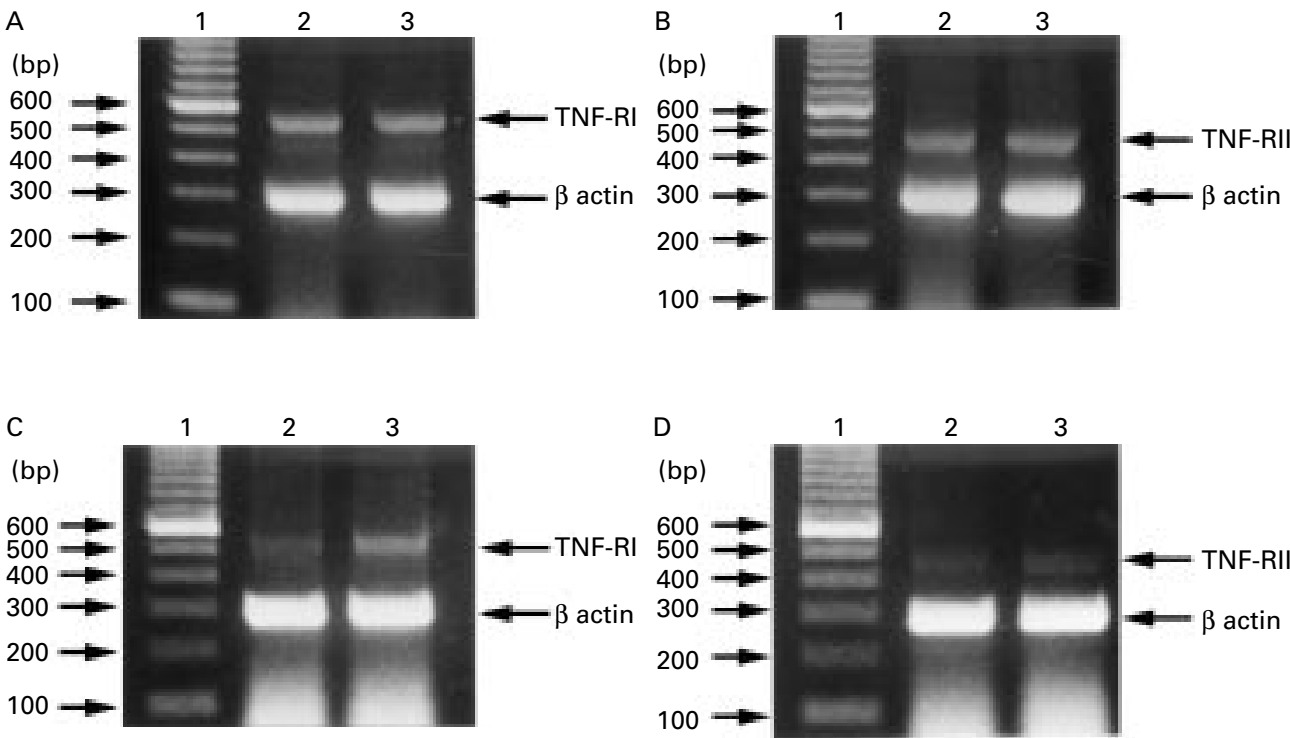

Figure 10 Detection of $m R N A$ for tumour necrosis factor receptor I (TNF-RI) and TNF-RII in gastric epithelial cells by reverse transcriptase polymerase chain reaction (PCR). Ethidium bromide stained gels containing PCR products of reverse transcribed TNF-RI $m R N A(A)$ and TNF-RII $m R N A$ (B) in MKN45 cells, and TNF-RI mRNA (C) and TNF-RII $m R N A$ (D) in KATO III cells. Lane 1, 100 bp DNA markers; lane 2, $m R N A$ from untreated cells; lane 3, $m R N A$ from cells treated with TNF $100 \mathrm{ng} / \mathrm{ml}$ for 96 hours. In $(A)$ and $(B), m R N A$ of lanes 2 and 3 were expressed equally. In (C) and (D), $m R N A$ of lane 3 was expressed slightly more strongly than that of lane 2.

A

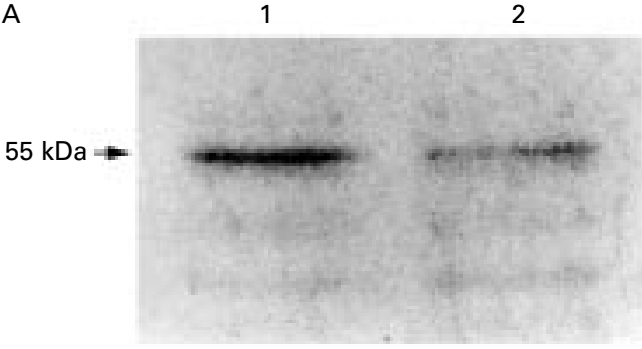

C

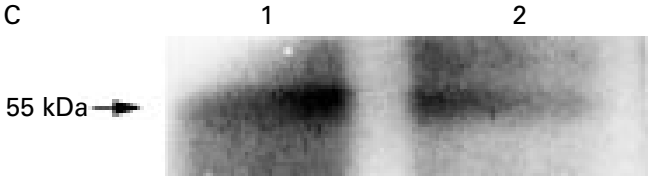

B

Figure 11 Immunoblotting analysis of membrane associated tumour necrosis factor (TNF) receptor I (TNF-RI) and TNF-RII on gastric epithelial cells with and without TNF (100 ng/ml) for 96 hours. (A) $55 \mathrm{kDa}$ TNF-RI in MKN45 cells; (B) $75 \mathrm{kDa}$ TNF-RII in MKN45 cells; (C) $55 \mathrm{kDa}$ TNF-RI in KATO III cells; (D) $75 \mathrm{kDa}$ TNF-RII in KATO III cells. Lane 1, untreated; lane 2, treated with TNF Expression of TNF-RI and TNF-RII decreased after treatment with TNF. 
did not reduce cell viability very much but neutralisation of both significantly reduced cell viability (fig 7). These results suggest that each sTNF-R may have the ability to block the effect of TNF.

The action of TNF on each cell type present in gastric mucosa of patients infected with $H$ pylori is not yet clear. However, as has been variously reported, it is thought that TNF is able to induce apoptosis in gastric epithelial cells. ${ }^{9}{ }^{10}$ We confirmed weak apoptosis by DNA laddering and flow cytometric analysis. It has been reported that apoptosis in gastric epithelial cells triggers glandular atrophy, reducing secretion of acid and pepsin, and thus is connected with carcinogenesis. ${ }^{7}$ It is also said that increased apoptosis may be the stimulus for a compensatory hyperproliferative and potentially preneoplastic response in chronic $H$ pylori infection. ${ }^{5}$ We surmise that gastric epithelial cells release sTNF-Rs as a protection against these dangers, thereby controlling the action of TNF. However, it is conjectured that, when the balance between TNF and STNF-Rs is upset, the action of TNF becomes predominant and causes cell damage, beginning with apoptosis.

In conclusion, this study suggests that TNF is produced after infection by $\mathrm{H}$ pylori, and this is accompanied by sTNF-R release from gastric epithelial cells. Moreover, release of sTNF-Rs from gastric epithelial cells and apoptosis induced by anti-sTNF-R monoclonal antibodies combined with TNF suggest that the soluble receptors regulate the action of TNF. In addition, TNF-R expression was confirmed to be downregulated. However, elucidation of the mechanism involved requires further research.

This work is supported by a Monbusho international scientific research program and a grant from the Ministry of Education, Science, and Culture, Japan. We would like to thank to $\mathrm{Mr} M$ Bodman, language consultant of our department, for suggestions on language and style.

1 Jaw TL, Li YW, Jin TW, et al. A nested case-control study on the association between Helicobacter pylori infection and gastric cancer risk in a cohort of 9775 men in Taiwan. Anticancer Res 1995;15:603-6.

2 Forman D, Newell DG, Fullerton F, et al. Association between infection with Helicobacter pylori and risk of gastric cancer: evidence from a prospective investigation. $B M f$ 1991;302:1302-5.

3 Parsonnet J, Friedman GD, Vandersteen DP, et al. Helicobacter pylori infection and the risk of gastric Helicobacter pylori infection and the ris
carcinoma. N Engl f Med 1991;325:1127-31.

4 Nomura A, Stemmermann GN, Chyou PH, et al. Helicobacter pylori infection and gastric carcinoma among Japabacter pylori infection and gastric carcinoma among Japanese Americans in Hawaii. N Engl f Med 1991;325:1132-6.
Moss SF, Calam J, Agarwal B, et al. Induction of gastric epiMoss SF, Calam J, Agarwal B, et al. Induction of gastric epi-
thelial apoptosis by Helicobacter pylori. Gut 1996;38:498thelial.

6 Jones NL, Yeger H, Cutz E, et al. Helicobacter pylori induces apoptosis of gastric antral epithelial cells in vivo. [abstract] Gastroenterology 1996;110:A933.

7 Mannick EE, Bravo LE, Zarama G, et al. Inducible nitric oxide synthase, nitrotyrosine and apoptosis in Helicobacter pylori gastritis: effect of antibiotics and antioxidants. Cancer Res 1996;56:3238-43.

8 Wagner S, Beil W, Westermann J, et al. Regulation of gastric epithelial cell growth by Helicobacter pylori: evidence for a major role of apoptosis.Gastroenterology 1997;113:183647 .

9 Noguchi K, Naito M, Kataoka S, et al. A recessive mutant of the U937 cell line acquired resistance to anti-Fas and antip55 tumor necrosis factor antibody-induced apoptosis. Cell Growth Differ 1995;6:1271-7.
10 Higuchi M, Aggarwal BB. Differentiation roles of two types of TNF receptor in TNF-induced cytotoxicity, DNA fragmentation, and differetiation. F Immunol 1994;152:4017 25.

11 Abreu-Martin MT, Vidrich A, Lynch DH, et al. Divergent induction of apoptosis and IL-8 secretion in HT-29 cells in response to TNF- $\alpha$ and ligation of Fas antigen. $f$ Immunol 1995;155:4147-54.

12 Nielsen H, Andersen LP. Chemotactic activity of Helicobacter pylori sonicate for human polymorphonuclear leucocyte and monocyte. Gut 1992;33:738-42.

13 Noach LA, Bosma NB, Jansen J, et al. Mucosal tumor necrosis factor- $\alpha$, interleukin- $1 \beta$, and interleukin- 8 production in patients with Helicobacter pylori infection. Scand $\mathcal{F}$ Gastroenterol 1994;29:425-9.

14 Crabtree JE, Shallcross TM, Heatley RV, et al. Mucosal tumor necrosis factor $\alpha$ and interleukin- 6 in patients with Helicobacter pylori associated gastritis. Gut 1991;32:14737.

15 Tartaglia LA, Goeddel DV. Two TNF receptors. Immunol Today 1992;13:151-3.

16 Heaney ML, Golde DW. Soluble hormone receptors. Blood 1993;82:1945-8.

17 Kohno T, Brewer MT, Baker SL, et al. A second tumor necrosis factor receptor gene product can shed a naturally occurring tumor necrosis factor inhibitor. Proc Natl Acad Sci USA 1990;87:8331-5.

18 Fernandez-Botran R. Soluble cytokine receptor: their role in immunoregulation. FASEB f 1991;5:2567-74.

19 Van Zee KJ, Kohno T, Fischer E, et al. Tumor necrosis factor soluble receptors circulate during experimental and clinical inflammation and can protect against excessive tumor necrosis factor $\alpha$ in vitro and in vivo. Proc Natl Acad Sci USA 1992;89:4845-9.

20 Austgulen R, Liabakk NB, Brockhaus M, et al. Soluble TNF receptors in amniotic fluid and in urine from pregnant woman. F Reprod Immunol 1992;22:105-16.

21 Girardin E, Roux-Lombard P, Grau GE, et al. Imbalance between tumor necrosis factor-alpha and soluble TNF receptor concentrations in severe meningococcaemia. Immunology 1992;76:20-3.

22 Kalinkovich A, Engelmann H, Harpaz N, et al. Elevated serum levels of soluble tumour necrosis factor receptors (sTNF-R) in patients with HIV infection. Clin Exp Immunol 1992;89:351-5.

23 Marshall BJ, Warren JR, Francis GJ, et al. Rapid urease test in the management of Campylobacter pyloridis-associated gastritis. Am f Gastroenterol 1987;82:200-10.

24 Prince AB.The Sydney system: histological division. 7 Gasroenterol Hepatol 1991;6:209-22.

25 Garcia-LLoret MI, Yui J, Winkler-Lowen B, et al. Epidermal growth factor inhibits cytokine-induced apoptosis of primary human trophoblasts. F Cell Physiol 1996;167:32432 .

26 Nicoletti I, Migliorati G, Pagliacci MC, et al. A rapid and simple method for measuring thymocyte apoptosis by propidium iodide staining and flow cytometry. F Immunol Methods 1991;139:271-9.

27 Dive C, Gregory CD, Phipps DJ, et al. Analysis and discrimination of necrosis and apoptosis (programmed cell death) by multiparameter flow cytometry. Biochim Biophys Acta 1992;1133:275-85.

28 Vermes I, Haanen C, Nakken HS, et al. A novel assay for apoptosis flow cytometric detection of phosphatidylserine expression on early apoptotic cells using fluorescein labelled Annexin V. f Immunol Methods 1995;184:39-51.

29 Murphy M, Pike-Nobile L, Soo VW, et al. Characterization of TNF receptors on human thymocytes. Thymus 1995;23: $177-94$.

30 Douvdevani A, Einbinder T, Yulzari R, et al. TNF receptors on human peritoneal mesothelial cells: regulation of receptor levels and shedding by IL- $1 \alpha$ and TNF $\alpha$. Kidney Int 1996;50:219-28.

31 Yano N, Endoh M, Naka R, et al. Altered synthesis of interferon- $\gamma$ and expression of interferon- $\gamma$ receptor by peripheral blood mononuclear cells from patients with IgA nephropathy and non-IgA proliferative glomerulonephritis. 7 Clin Immunol 1996;16:71-9.

32 Ishizuka T, Morita K, Hisada T, et al. The direct effect of interferon- $\gamma$ on human eosinophilic leukemia cell lines: the induction of interleukin-5 mRNA and the presence of an interferon- $\gamma$ receptor. Inflammation 1996;20:151-63.

33 Dummer RD, Heald PW, Nestle FO, et al. Sézary syndrome T-cell clones display T-helper 2 cytokines and express the accessory factor- 1 (interferon- $\gamma$ receptor $\beta$-chain). Blood 1996;88:1383-9.

34 Fioryccu S, Santucci L, Migliorati G, et al. Isolated guinea pig gastric chief cells express tumour necrosis factor receptors coupled with the sphingomyelin pathway. Gut 1996;38:182-9.

35 Thomas B, Paul N. Tumor necrosis factor- $\alpha$ modulates the expression of its p60 receptor and several cytokines in rat tracheal epithelial cells. F Immunol 1996;157:3089-96.

36 Poll T, Coyle SM, Kumar A, et al. Down-regulation of surface receptors for TNF and IL-1 on circulating monocytes and granulocytes during human endotoxemia. F Immunol 1997;158:1490-7. 